\title{
SCIENTIFIC COMMUNICATION
}

\section{FIRST REPORT OF Pestalotiopsis diospyri CAUSING CANKER ON PERSIMMON TREES ${ }^{1}$}

\author{
GISELDA ALVES ${ }^{2}$, FRANCINEIA SILVA VERBISKI ${ }^{3}$, THEMIS J. MICHAILIDES ${ }^{4}$, \\ LOUISE LARISSA MAY-DE MIO
}

\begin{abstract}
During 2006 to 2009 season symptoms of a canker disease were observed on twigs and branches of young and mature persimmon trees (Diospyros kaki L.) cv. Fuyu in the States of Santa Catarina and Paraná in the Southern Brazil. The cankers result in severe damage and reduced production. Isolations from the margins of these cankers revealed a genus of Pestalotiopsis. Koch's postulates were confirmed using two isolates of the pathogen which was identified as Pestalotiopsis diospyri.
\end{abstract}

Index terms: disease, inoculation, detection, Diospyros kaki.

\section{PRIMEIRA OCORRÊNCIA DE Pestalotiopsis diospyri CAUSANDO CANCROS EM CAQUIZEIROS}

RESUMO - Durante as safras de 2007 a 2009, foram observados sintomas de cancro em ramos e galhos de plantas de caquizeiro (Diospyros kaki L.) cv. Fuyu, nos Estados de Santa Catarina e do Paraná, no Sul do Brasil. Os cancros resultavam em danos severos e comprometiam a produção. Após o isolamento da margem dos cancros, detectou-se o gênero Pestalotiopsis em todas as amostras. Os postulados de Koch foram confirmados, utilizando-se dois isolados do patógeno, o qual foi identificado como Pestalotiopsis diospyri. Termos para indexação: doença, inoculação, detecção, Diospyros kaki.

Persimmon (Diospyros kaki L.), originally from Asia, is a highly productive fruit tree and cultivated in almost all countries that have subtropical and temperate climate (KITAGAWA \& GLUCINA, 1984). In Brazil, the persimmon crop is very common, especially in the Southeast and South regions, mainly in the state of São Paulo $(88,223$ ton in 3,559 ha), Rio Grande do Sul (30,237 ton in 2,147 ha) and Paraná (22,318 ton in 1,539 ha) (IBGE, 2008).

Persimmon is a vigorous plant, which makes it suitable to be cultivated in organic systems resulting in growers' high revenues because the fruit can be more valuable than the fruit produced in conventional systems. Furthermore, fruit produced in such way are important socioeconomically due to the increasing demand as a product for export to foreign markets. However, the presence of cankers in trees under organic, agro-forestry, and conventional orchard systems has been a limitation factor for persimmon production in Brazil and has increased the frustration of persimmon producers in the State of Paraná (Campina Grande do Sul and Bocaiúva do Sul municipalities) and Santa Catarina (Monte Castelo municipality), which are considered the main persimmon producing areas. The goal of this study was to identify the pathogen of these cankers on persimmon trees.

Branches of persimmon cultivar 'Fuyu' exhibiting cankers were collected from Santa Catarina and Paraná for isolation of putative pathogen(s). Isolations were made by cutting $3 \times 3 \times 3 \mathrm{~mm}$ pieces of woody tissues from the margins of cankers, surface sterilized in a $10 \%$ of chlorine solution, blotted on clean paper towels, and plated on potato-dextroseagar 20\% (Himedia Laboratories, Pvt. Ltd, MumbaiIndia) acidified with lactic acid at $0.1 \%$. The plates with the canker tissues were incubated at $25 \pm 2{ }^{\circ} \mathrm{C}$, with a photoperiod of 12 hours for 6 days. Colonies developed from the woody tissues had white mycelia and exhibited a radial growth at the end of the incubation period, with the formation of dark masses of acervuli containing conidia. The identification

\footnotetext{
'(Trabalho 187-10). Recebido em: 16-08-2010. . Aceito para publicação em: 19-11-2010.

${ }^{2}$ Eng. Agr., Doutoranda Produção Vegetal/UFPR/SCA/DFF, Curitiba-PR. CEP 80035-050. E-mail: giseldaalves@uol.com.br. ${ }^{3}$ Eng. Agr. /UFPR/SCA/DFF, Curitiba-PR. CEP 80035-050. E-mail: francineia.sv@gmail.com

${ }^{4}$ Department of Plant Pathology, University of California-Davis, Kearney Agricultural Center, Parlier 93648. E-mail: themis@uckac.edu ${ }^{5}$ Eng. Agr., Prof ${ }^{a}$. Dr ${ }^{\mathrm{a}}$ UFPR/SCA/DFF, Rua dos Funcionários, 1540, Curitiba-PR. 84030-900. E-mail: maydemio@ufpr.br
} 
of the consistently recovered fungus was based on the characteristic morphology and appendages of the conidia (GUBA, 1961). Pathogenicity tests were carried out inoculating $10^{4}$ conidia $\mathrm{mL}^{-1}$ of the pathogen onto "Fuyu" persimmon trees with 2.5 years old kept in greenhouses with $25^{\circ} \mathrm{C} \pm 2$ e $80 \%$ of humidity during 24 hours. During the next two months the evaluation of the symptoms incidence and reisolations were performed.

All the isolates obtained from the cankers were identified as the genus of Pestalotiopsis. The colonies had a characteristic yellow central area and lacked the black mass of spores. These isolates had straight conidia observed microscopically $(100 \times$ magnification), occasionally curved, and consisted of five eusepted cells, with the three median cells olivegreen or dark brown color and two hyaline end cells, bearing two or three apical appendages and one basal appendage (Figure 1-C). The average length of conidia was $28.08 \mu \mathrm{m}$, of the apical appendages (three, predominantly) $19.90 \mu \mathrm{m}$, and of the basal appendage $7.63 \mu \mathrm{m}$. The fungus was identified as Pestalotiopsis diospyri (Sydow et P. Sydow) Rib. Souza on the basis of conidial and cultural characteristics. This species was reported in Brazil in the state of Rio de Janeiro, causing lesions on leaves of persimmon (SOUZA, 1985). In November 2006, $P$. diospyri was reported to be present on calyxes of unhealthy persimmon fruits in different production regions in New Zealand and for the first time, pathogenicity of Pestalotiopsis was demonstrated on sweet persimmon fruit in Spain (BLANCO et al., 2008). Tuset et al. (1999) in Spain reported circular, grey-brownish foliar spots caused by Pestalotiopsis theae, in sweet persimmon fruits, with subsequent defoliation; however they did not observe cankers affecting the branches. They also observed necrotic calyxes in more than $90 \%$ of harvested sweet persimmon fruits of the cultivar Triumph, in orchards located in Huelva Province, Spain. In addition, brown to black necrotic areas appeared on the fruit sepals. Reports of necrotic spots on leaves and fruits, as well as calyx necrosis due to Pestalotiopsis psidii have been published for guava (CARDOSO et al., 2002), coconut (CARDOSO et al., 2003), macadamias (RAWAL \& MUNIYAPPA, 1981), African oil palm trees (ARAÚJO et al., 1991), and ornamental plants (BARGUIL et al., 2008; PESSOA et al., 2008, Serra et al., 2007.

Pathogenicity tests were carried out inoculating $10^{4}$ conidia $\mathrm{mL}^{-1}$ of Pestalotiopsis diospyri onto "Fuyu" persimmon trees with 2.5 years old kept in greenhouse with $25^{\circ} \mathrm{C} \pm 2$ e $80 \%$ of humidity. Initial symptoms were observed as elliptical to round brownish lesions (3.5 $\mathrm{mm}$ in diameter) with defined margins 4 days after inoculation (Figure 1-D). By day 90 , these lesions reached $40 \mathrm{~mm}$ in diameter, leaving the woody tissues exposed (Figure 1-G). At last, the fungus was reisolated from the infected plants tissue which one had been artificially infected, therefore fulfilling Koch's postulates. Acervuli with exuding black masses of conidia (Figure 1-B) were observed at the margins of the cankers. According to field observations relatively high air humidity and high temperatures favor the spread of the conidia, mainly by water or wind under drier conditions. Healthy plants, especially the young ones, are infected easily, if they are near infected ones. In plants of the Arecaceae family, a distinct species of Pestalotiopsis infects previously injured areas (CARDOSO et al., 2003). These infections are also in association with other pathogens (RAM, 1989) or with insects (ARAÚJO et al., 1991). However, infections of persimmon as it has been observed in this report, $P$. diospyri infect intact plants, without the need for a wound. Therefore, $P$. diospyri from persimmon is considered as no opportunistic fungi and there was no association to other agents and/or insect wounds. Therefore, this species is considered as a primary pathogen of persimmon. This is the first report Pestalotiopsis diospyri causing cankers on branches of persimmon trees in the state of Paraná.

Lesions on sepals, fruits and defoliation, as described by others authors, are also observed in the production areas of persimmon in the south of Brazil. Another canker has been observed mainly on young twigs caused by Colletotrichum gloeosporioides which has become very important in the last years. The importance of both cankers diseases on persimmon production needs to be assessed. 


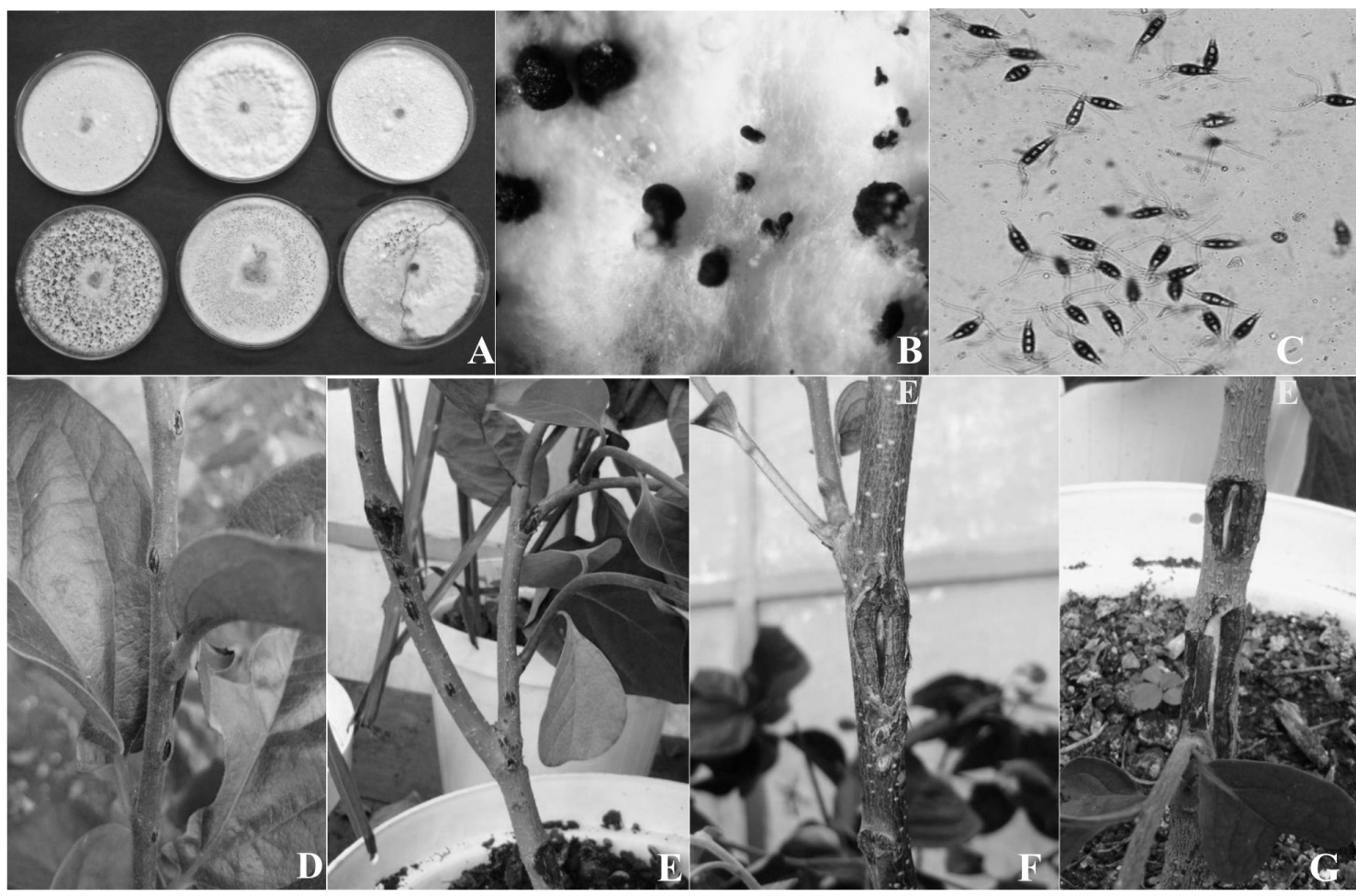

FIGURE 1 - A: Pestalotiopsis colonies on Potato-Dextrose-Agar 20\% (BDA) + lactic acid 0.1\%, with and without a black mass of exuded spores; B: Acervuli with exuded conidia; C: Conidia with apical and basal appendages; D: Canker formation in branches of persimmon cultivar "Fuyu"; E: Symptoms in the primary branch of persimmon; F and G: Advanced symptoms in branches. (Photos: Verbiski, F.S., 2009)

\section{REFERENCES}

ARAÚJO, J.C.A.; GASPAROTTO, L.; GARCIA, M.V.B. Epidemiologia de Pestalotiopsis spp em dendezeiro. Fitopatologia Brasileira, Brasília, v.16, n.2, p.33, 1991.

BARGUIL, B.M.; PESSOA, W.R.L.S.; OLIVEIRA, S.M.A.; COELHO, R.S.B. Ocorrência de Pestalotiopsis neglecta em Ananas lucidus. Summa Phytopathologica, Botucatu, v.34, n.1, p.96, 2008.

BLANCO, C.; ROMERO, F.; DE LOS SANTOS, B. First Report of Pestalotiopsis dyospiri Causing Calyx Blight of Sweet Persimmon in Huelva Province (Southwestern Spain). Plant Disease, St Paul, v. 92, n.1, p.176, 2008.

CARDOSO, G.D.; BARRETO, A.F.; ARAÚJO E.; ALMEIDA, F.A; CARVALHO, R. A.G. Etiologia e progresso da mancha de pestalotia do coqueiro ( $\mathrm{Co}$ cos nucifera L.), em São Gonçalo, Paraíba. Revista Brasileira de Fruticultura, Jaboticabal, v.25, n.2, p.335-336, 2003.
CARDOSO, J.E.; MAIA, C.B.; PESSOA, M.N.G. Ocorrência de Pestalotiopsis psidii e Lasiodiplodia theobromae causando podridão no caule da goiabeira no Ceará. Fitopatologia Brasileira, Brasília, v.27, n.3, p.320, 2002.

IBGE - INSTITUTO BRASILEIRO DE GEOGRAFIA E ESTATÍSTICA. Produção Agrícola Municipal. Disponível em <www.sidra.ibge.gov. br>. Acesso em julho de 2010.

GUBA, E.F. Monograph of Monochaetia and Pestalotia. Harvard University Press, Cambridge, MASS, $1961.342 \mathrm{p}$.

KITAGaWA, H.; GLUCINA, P.G. Persimmon culture in New Zealand. Wellington, 1984. 69p.

PESSOA, W.R.L.S.; BARGUIL, B.M.; OLIVEIRA, S.M.A.; COELHO, R.S.B. Ocorrência de Pestalotiopsis palmarum em Caryota mitis. Summa Phytopathologica, Botucatu, v.34, n.1, p.95, 2008. 
RAM, C. Microflora associada à queima-das-folhas do coqueiro. Fitopatologia Brasileira, Brasília, v.14, n.4, p.36-38, 1989.

RAWAL, R.D.; MUNIYAPPA, N.C. A new disease of macadamia. Current Science, Bangalore, v.50, n.23, p.1035, 1981.

SERRA, I.M.R.S.; COELHO, R.S.B. Mancha de pestalotiopsis em helicônia: caracterização da doença e potenciais fontes de resistência. Fitopatologia Brasileira, Brasília, v.32, n.1, p.44-49, 2007.
SOUZA, A.F.R. Estudo taxonômico do gênero Pestalotiopsis Stey. Melanconiaceae, Rodriguesia, Rio de Janeiro, v.37, n.63, p.21-26, 1985.

TUSET, J.; HINAREJOS, C.; MIRA, J.L. First report of leaf blight on sweet persimmon tree by Pestalotiopsis theae in Spain. Plant Disease, St Paul, v. 83, p.1070, 1999. 